Tohoku J. exp. Med., 1974, 113, 129-133

\title{
Stomach Cancer and Ecologic Factors in Japan
}

\author{
Euji Takahashi \\ Department of Hygiene, Tohoku University School of Medicine, \\ Sendai
}

TAKAHASH, E. Stomach Cancer and Ecologic Factors in Japan. Tohoku J. exp. Med., 1974, 113 (2), 129-133 — The correlation between mortality rate from stomach cancer and some basic ecological factors such as average temperature, sunshine duration and mineral content of river water is studied on 46 prefectures in Japan. Peculiar geographic distribution of the death rate from stomach cancer in Japan is as already introduced by Segi and others. The river water quality is expressed as the ratio of $\mathrm{Ca} / \mathrm{SO}_{4}$. The negative correlation coefficients of male age-adjusted stomach cancer mortality rate with yearly sunshine duration and with $\mathrm{Ca} / \mathrm{SO}_{4}$ ratio of river water were significant, but no correlation was found with yearly average temperature. The meaning of the significant correlation is interpreted as follows. Sulfate and chloride seemed to be aetiological agents to make inflammation - which sometimes develops into ulcer, polypus and cancer - in stomach mucous membrane. On the contrary calcium has antiphlogistic effect, because of its capillary permeability reducing action, which may also prevent lodging of tumour cells in haematogenous metastasis of cancer in microcirculation system. The sunshine duration may be concerned with calcium absorption through its action of vitamin D production on skin.

stomach cancer; environmental factors of stomach cancer; ecologic factors of stomach cancer; geographical pathology of stomach cancer; water quality and stomach cancer

Japan, as well as Chile and Iceland, is among the countries of the highest mortality for stomach cancer, as reported by Segi (1960) and Segi and Tsukahara (1965). Peculiar geographic distribution of the death rate within Japan is also well known (Segi and Kurihara 1960; Segi et al. 1965). Study on the peculiar inclination of the geographic distribution of mortality rate sometimes suggests some clues to approach the pathogenesis of stomach cancer.

In the present paper the correlation between the mortality rate from stomach cancer and some basic ecological factors such as average temperature, sunshine duration and mineral content of river water in 46 prefectures in Japan is studied and discussed.

\section{Materials and Methods}

Age-adjusted death rate from stomach cancer for each prefecture in 1960 and 1970 used in the present study are taken from data of the national mortality statistics made by the Ministry of Health and Welfare of Japan (1964, 1973). Yearly average temperature and yearly sunshine duration are adopted from data observed at the meteorological observatories for 30 years from 1931 to 1960 (Tokyo Astronomical Observatory 1970).

Received for publication, March 20, 1974. 
For a few small prefectures which have no meteorological observatory, data from the nearest observatory is employed.

Regarding the mineral content of river water for each prefecture, the ratio of calcium over sulfate is adopted from the data of Kobayashi (1960) on 225 rivers in Japan, which are partly reported in "Data of Geochemistry," sixth edition (U.S., Geological Survey Professional Paper 440-G). The survey on river water quality was carried out during the period of 1943-1958, mostly measured from 6 to 12 times for the same river in different season. Items measured were $\mathrm{Ca}, \mathrm{Mg}, \mathrm{K}, \mathrm{HCO}_{3}, \mathrm{SO}_{4}, \mathrm{Cl}, \mathrm{SiO}_{2}, \mathrm{Fe}, \mathrm{PO}_{4}, \mathrm{NO}_{3}-\mathrm{N}, \mathrm{NH}_{4}-\mathrm{N}$, etc. However, to simplify the expression of river water quality the ratio of $\mathrm{Ca} / \mathrm{SO}_{4}$ is selected. Those are the representative elements respectively in base and acid radicals of river water. Calcium content of river water seems to have relatively important meaning for Japanese people, especially in agricultural area, who have not a dietary custom to take milk.

Japan is an island country on the circum-Pacific volcanic belts, and has many hot springs rich in sulfate. According to Kobayashi (1957), Japanese river water has more $\mathrm{SO}_{4}$ content than the world average. Physical effect of sodium and chlorine in drinking water appears to be negligible compared with those in salted pickles and miso soup in Japan. Although the content of $\mathrm{HCO}_{3}$ - ion is more than other anions, the meaning of it in drinking water does not seem to be so important for human body, compared to $\mathrm{Ca}^{2+}$ and $\mathrm{SO}_{4}{ }^{2-}$ ions. The contents of $\mathrm{K}^{+}, \mathrm{PO}_{4}{ }^{3-}, \mathrm{NO}_{3}^{-}$and $\mathrm{NH}_{4}^{+}$ions are far smaller and seem to be negligible. The ratio of $\mathrm{Ca}^{2+} / \mathrm{SO}_{4}{ }^{2-}$ strongly correlates with the ratio of $(2 \mathrm{Ca}+2 \mathrm{Mg}+\mathrm{Na}+\mathrm{K}) /\left(2 \mathrm{SO}_{4}+\right.$ $\mathrm{Cl}+3 \mathrm{PO}_{4}+\mathrm{NO}_{3}$ ).

River water was collected at the upper stream of cities, industries and agricultural fields to avoid the influence of artificial pollution.

\section{Results}

Stomach cancer mortality is high in prefectures along the Sea of Japan in the northern part of Honshu, the main island, as well as in Osaka and the neighbouring Prefecture Nara which locate east to the Inland Sea Seto. The mortality is low in the southwestern part of Honshu, and Shikoku and Kyushu, as shown in Fig. 1. Although the figure shows the male death rate distribution, that for female is

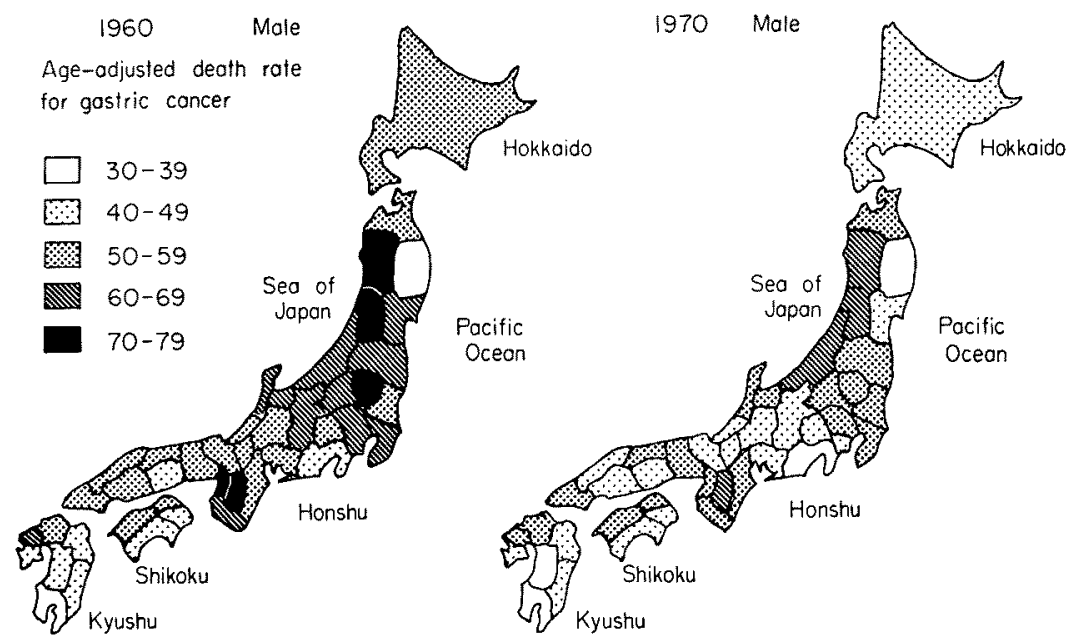

Fig. 1. Geographic distribution of male death rate for gastric cancer in 1960 and 1970 in Japan. 
similar to that for male in general, as Segi and Kurihara (1960) stated.

The Japanese islands spread from about $30^{\circ} \mathrm{N}$ to $45^{\circ} \mathrm{N}$ and the climate is a little different between in the southern part and in the northern part. The yearly average of temperature in Sapporo, the capital city in Hokkaido, the northern island, is $7.6^{\circ} \mathrm{C}$, and that in Kagoshima, the capital city in the southmost prefecture except Okinawa, is $16.8^{\circ} \mathrm{C}$. The yearly sunshine duration is different between the slope of the Japanese Sea side and that of the Pacific side. In winter the cold monsoon from the continent passing over the Japanese Sea, tossing the spinal mountain range of the main island drifts heavy snow on the Japanese Sea side slope and cloudy weather prevails during winter there. Monthly sunshine duration sometimes diminishes below 50 hours in winter, and also yearly sunshine duration is less in the Japanese Sea side slope than in the Pacific side slope where it is rather clear even in winter.

As for the geographic distribution of river water quality, as Kobayashi stated, the rate of sulfate type (i.e. $\mathrm{Ca}^{2+} / \mathrm{SO}_{4}{ }^{2-}$ index is low) increases as we go to northeastern region of the main island. Only exception is the Pacific-side prefecture (Iwate) of that region, with Lias coast, which geologically is covered with chalk in places. On the contrary, in the western region of the main island and Shikoku and $\mathrm{Kyushu}$, most river water shows carbonate type or normal type (i.e. $\mathrm{Ca} / \mathrm{SO}_{4}$ index is greater).

As seen in Table 1, correlation coefficients of age-adjusted stomach cancer mortality rate with yearly average temperature in 46 prefectures are not significant $(p>0.05)$. The negative correlation coefficients of male mortality with yearly

TABLE 1. Correlation coefficients between age-adjusted gastric cancer mortality and ecologic factors in 46 prefectures

\begin{tabular}{|c|c|c|c|c|}
\hline Sex & Year & $\begin{array}{l}\text { Yearly average } \\
\text { temperature for } \\
1931 / 60\left({ }^{\circ} \mathrm{C}\right)\end{array}$ & $\begin{array}{l}\text { Yearly sunshine } \\
\text { duration for } \\
1931 / 60 \text { (hour) }\end{array}$ & $\begin{array}{c}\text { Mineral constituent } \\
\text { of river water } \\
\left(\mathrm{Ca} / \mathrm{SO}_{4}\right)\end{array}$ \\
\hline Male & $\left\{\begin{array}{l}1960 \\
1970\end{array}\right.$ & $\begin{array}{l}-0.246 \\
-0.135\end{array}$ & $\begin{array}{l}\dagger-0.378 \\
\pm-0.544\end{array}$ & 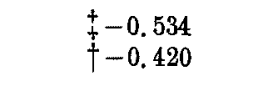 \\
\hline Female & $\left\{\begin{array}{l}1960 \\
1970\end{array}\right.$ & $\begin{array}{l}-0.106 \\
-0.034\end{array}$ & $\begin{array}{l}-0.069 \\
-0.066\end{array}$ & $\begin{array}{r}-0.291 \\
-0.259\end{array}$ \\
\hline
\end{tabular}

* $\mathrm{P}<0.05, \dagger \mathrm{P}<0.01, \ddagger \mathrm{P}<0.001$.

TABLE 2. Partial correlation coefficients between age-adjusted gastric cancer mortality and ecologic factors in 46 prefectures

\begin{tabular}{|c|c|c|c|c|c|c|}
\hline Sex & Year & $\mathrm{r}_{12.3}$ & $r_{13.2}$ & $r_{13.4}$ & $\mathrm{r}_{14.2}$ & $\mathbf{r}_{14.3}$ \\
\hline \multirow[t]{2}{*}{ Male } & 1960 & -0.050 & $*-0.300$ & $\dagger-0.353$ & \pm-0.507 & $\ddagger-0.520$ \\
\hline & 1970 & 0.228 & \pm-0.568 & $\stackrel{+}{\ddagger}-0.535$ & $\dagger-0.404$ & $\dagger-0.405$ \\
\hline \multirow[t]{2}{*}{ Female } & 1960 & -0.082 & -0.013 & -0.024 & -0.276 & -0.284 \\
\hline & 1970 & 0.002 & -0.057 & -0.026 & -0.258 & -0.252 \\
\hline
\end{tabular}

1: age-adjusted gastric cancer mortality, 2 : yearly average temperature, 3 : yearly sunshine duration, 4: mineral constituent of river water $\left(\mathrm{Ca} / \mathrm{SO}_{4}\right)$. 
sunshine duration and those with $\mathrm{Ca}^{2+} / \mathrm{SO}_{4}{ }^{2-}$ ratio of river water are significant $(\mathrm{P}<0.01)$.

Table 2 shows partial correlation coefficients of first order between age-adjusted stomach cancer mortality rate and ecologic factors in 46 prefectures. The negative correlation between stomach cancer mortality and sunshine duration is significant even when average temperature or river water quality is constant. At the same time the negative correlation between the mortality and the river water quality is significant even when average temperature or sunshine duration is constant.

\section{Discussion}

Although significant correlationship does not always mean causality, some relationship between the stomach cancer mortality and sunshine duration or river water quality might be suspected. The longer the sunshine duration and the higher the ratio of $\mathrm{Ca}^{2+} / \mathrm{SO}_{4}{ }^{2-}$ in river water, the lower the stomach cancer mortality is. Some relation might be imagined between both correlationship: when the sunshine duration is long, vitamin $\mathrm{D}$ production at skin will increase, and in consequence calcium absorption in the intestinal tract will be promoted.

In Japan since about 1926 city water has been analysed only for the purpose of prevention of infectious diseases of digestive system, but not for detailed mineral content, therefore we have no data about it. The present data of the chemical nature of river water have derived from Kobayashi's study of the nature of irrigation water from the agricultural standpoint. In Japan river water is generally soft and city water is not treated for softening. Therefore, the mineral content in supplying water is not so different from that in irrigation water.

Sato et al. (1959) suspected strongly salted foods as an etiologic factor of gastric cancer which prevails most in Japan. They confirmed by animal experiment with mice that strongly salted food injured mucous membrane of stomach. Geographically recognizing lower distribution of stomach cancer mortality in areas of limestone, Minowa et al. (1960) tried to confirm the favourable effect of calcium by animal experiment with mice. In the animal group fed with food containing $\mathrm{NaCl}$ in $10 \%$ and $\mathrm{Ca}$ below $4 \%$, atrophy of stomach mucous membrane coupled with slight bleeding was recognized a week later. But in animal group kept with food containing $\mathrm{NaCl}$ in $10 \%$ and $\mathrm{Ca}$ over $6 \%$, no striking pathologic change such as congestive atrophy of stomach mucous membrane was found except very slight tumour.

Acid such as $\mathrm{H}_{2} \mathrm{SO}_{4}$ and $\mathrm{HCl}$ has a nature to make inflammation on skin or mucous membrane, and it is well-known that repeated inflammation sometimes makes ulcer, polypus and cancer. Although stomach is a hydrochloric acid secreting organ, chronic exposure to too strong acid may make inflammation there.

On the contrary calcium has an effect to reduce capillary permeability and to prevent effusion (Mönninghoff et al. 1972), and calcium preparation is sometimes used as antiphlogistic. Therefore, calcium and acids are mutually antagonistic 
to make inflammation of stomach mucous membrane.

Stomach cancer is inclined to make metastasis mainly through lymphatic system or blood circulation. According to Sato and Suzuki (1972), the mechanism of the lodging of tumour cells is an important process in haematogenous metastasis of cancer in microcirculation system. It may not be so difficult to suppose that plasma calcium may chronically drop in some grade by living condition of calciumand vitamin-D-deficient diet - besides that in the Japanese Sea side slope of northern Honshu the people lack in ultraviolet ray exposure especially for long winter - with strongly salted food and drinking water of low ratio of $\mathrm{Ca}^{2+} / \mathrm{SO}_{4}{ }^{2-}$, chance of cancer metastasis may increase. Kamiyama et al. (1970) measured calcium level in the sera of 2,071 persons aged forty and over in agricultural and fishing villages in Tohoku region of Japan, and found the number of persons with low serum calcium (below $8.0 \mathrm{mg} / 100 \mathrm{ml}$ ) had increased in advancement of age group, especially in the agricultural village.

\section{References}

1) Kamiyama, S., Sudo, K., Arai, K. \& Watanabe, T. (1970) Ecological studies on physical condition and blood chemistry in farm and fishing village in Tohoku region of Japan. II. Comparison of blood levels of minerals. Minzoku-Eisei (Jap.) (Race Hyg. \& Hum. Ecol.), 36, 26-36.

2) Kobayashi, J. (1957) On geographical relationship between the chemical nature of river water and death rate from apoplexy. Ber. Ohara Inst. landwirts. Biol., 11, $12-21$.

3) Kobayashi, J. (1960) A study on the mean quality of Japanese river water and its characteristics. Nogaku Kenkyu (Jap.) (Agricul. Research), 48, 63-106.

4) Ministry of Health and Welfare (1963) Vital Statistic Special Report - Age-Adjusted Death Rate for Selected Causes in 1960 (Jap.), Tokyo, pp. 38-4l.

5) Ministry of Health and Welfare (1973) Age adjusted death rate for main causes in 1970. Kosei-no-Shihyo (Jap.), 20, No. 9, 261-262.

6) Minowa, S., Takahashi, H., Kano, T., Matsuyama, K. \& Araki, Y. (1960) Studies on the relation between cancer and calcium. 3. Histological study on injury by salt in stomach mucosa and efficacy of calcium against it. Kitakanto-Igaku (Jap.), 10, 713718.

7) Mönninghoff, W., Thermann, H. \& Westphal, U. (1972) Elektronenmikroskopische Untersuchungen über den Einfluss von Magnesium- und Calcium-Chelaten auf die Capillarpermeabilität im Herzmuskel der Maus. Res. exp. Med., 157, 123-135.

8) Sato, N. \& Suzuki, M. (1972) Experimental studies on metastasis formation, with special reference to the mechanism of cancer cell lodgment in the microcirculation. Excerpta Med. Intern. Congr. Ser., 269, 168-176.

9) Sato, T., Fukuyama, T. \& Suzuki, T. (1959) On lesions of stomach mucous membrane by strongly salted foods. Nihon-Ijishinpo (Jap.), No. 1835, 25-27.

10) Segi, M. (1960) Cancer Mortality for Selected Sites in 24 Countries (1950-1957). Dep. Publ. Hlth., Tohoku Univ. Sch. Med., Sendai, pp. 260-261.

11) Segi, M. \& Kurihara, M. (1960) Cancer in Japan from the viewpoint of geographical pathology. Tohoku J. exp. Med., 72, 169-193.

12) Segi, M., Kurihara, M. \& Matsuyama, T. (1965) Cancer Mortality in Japan (18991962). Dept. Publ. Hlth., Tohoku Univ. Sch. Med., Sendai, pp. 29-32.

13) Segi, M. \& Tsukahara, Y. (1965) Comparison of the age-adjusted death rates for cancer in Iceland and Norway. Tohoku J. exp. Med., 87, 301-305.

14) Tokyo Astronomical Observatory (1970) Rika-Nenpyo (Scientific Chronological Tables), Maruzen, Tokyo, Meteorology pp. 8-9, 20-21. 